\title{
PHYSICO-CHEMICAL CHARACTERIZATION OF WATER WELLS FROM REMETI, MARAMURES
}

\author{
THOMAS DIPPONG ${ }^{a, b}$, CRISTINA MIHALl ${ }^{a, b}$, OANA MARE ROSCA ${ }^{a, b}$, \\ MONICA MARIAN ${ }^{a, b}$, MARIA MAGDALENA PAYER ${ }^{b}$, \\ MARCEL ȚÎBÎRNAC ${ }^{b}$, SEBASTIAN BUD ${ }^{a}$, GEORGE COMAN ${ }^{a}$, \\ ENIKO KOVACS ${ }^{c, d}$, MARIA-ALEXANDRA HOAGHIA ${ }^{c *}$
}

\begin{abstract}
This study was conducted with the aim of determining the quality and potential contamination level of water wells. Samples were collected from private water wells used as drinking water sources in Remeți locality, Maramures County, Romania. Remeți is situated near the protected area of the Upper Tisa River. Several physico-chemical indicators were determined, such as $\mathrm{pH}$, electrical conductivity, dissolved oxygen, oxygen saturation, turbidity, temperature, ammonium, nitrate, nitrite, chloride, phosphate, iron, copper, sulphates, carbonate, bicarbonate and total hardness, due to their importance to human health and to the quality of the aquatic systems situated nearby a protected area. The quality status was assessed by using the water quality index (WQI), based on eleven parameters: $\mathrm{pH}$, electrical conductivity, ammonium, total hardness, turbidity, nitrite, nitrate, chloride, sulphate, iron and cooper. The results indicated high amounts of ammonium and nitrate, while the WQI classified the studied water well samples into excellent and good quality categories. The WQI scores ranged between 27.7 and 65.1. The novelty of the study consists in the determination of the chemical composition of water wells from Remeti locality and in identification of some pollution processes which could affect human health if the studied waters are used as drinking water sources.
\end{abstract}

Keywords: water quality, physico-chemical parameters, water quality index

a Technical University of Cluj-Napoca, Faculty of Sciences, Department of Chemistry and Biology, 76 Victoriei Street, 430122 Baia Mare, Romania

b Heidenroslein Association, 12A/95 Unirii Street, 430122 Baia Mare, Romania

c INCDO-INOE 2000, Research Institute for Analytical Instrumentation, 67 Donath Street, 400293 Cluj-Napoca, Romania

d University of Agricultural Sciences and Veterinary Medicine, 3-5 Calea Manastur, 400372, Cluj-Napoca, Romania

*Corresponding author: alexandra.hoaghia@icia.ro 
THOMAS DIPPONG, CRISTINA MIHALI, OANA MARE ROSCA, MONICA MARIAN, ...

\section{INTRODUCTION}

The quality of water, an essential factor of the environment, is defined as an assembly of physical, chemical, biological and bacteriological characteristics numerically expressed. These characteristics classify each water sample into a certain category [1-4]. Groundwater is considered the most reliable source of fresh water. Almost $80 \%$ of the Earth's population depend on groundwater resources (used as drinking water sources) due to their quality compared with surface waters, which need chemical treatment and decontamination procedures [5]. Water with an adequate chemical composition is essential for the health and thriving of human life [6]. In order to determine the quality of groundwater, the impact of diverse indicators $(\mathrm{pH}$, electrical conductivity, total dissolved solids, total hardness, chloride, nitrate, sulphate, fluoride, calcium, magnesium, sodium and potassium) of the water's chemistry is assessed [7].

In Romania, a representative part of the population uses groundwater resources from water wells for drinking purposes. Groundwater resources are exploited through centralized water supply systems and by using private and public water wells. The quality of water distributed by public networks needs to follow the quality standards regarding potability. On the other hand, the water wells are characterized by high amounts of various chemical parameters (ammonium, nitrate, nitrite, sulphate, chloride), mostly higher than the maximum allowable limits established by Romanian and international regulations referring to drinking water quality $[8,9]$. Anthropogenic activities, as well as natural factors and processes are sources of high concentrations of diverse chemicals and toxic compounds [10]. The variation of the chemical composition depends on physico-chemical processes, such as the interaction between water, soil or rocks, the dilution of various chemical substances or ionic phases, the composition of infiltrated water, precipitation and biochemical reactions $[6,11]$.

Temperature is an important indicator in determining the quality of natural and residual waters. It influences the chemical composition, since the solubility of chemicals depends on it [1,3]. The increasing of temperature intensifies the speed of water molecules motion and implicitly of the physicochemical and biochemical processes [3].

Turbidity is determined by suspended materials (clay, dissolved substances, organic and inorganic materials, plankton and microorganisms) [4]. Water with high turbidity cannot be used for drinking purposes or used as industrial water, due to the unproper appearance and to the potential danger for human health [4]. 
Electrical conductivity represents the capacity of water to transport electricity, being corelated with the total quantity of dissolved salts and the estimated number of dissolved minerals $[1,12]$.

The $\mathrm{pH}$ indicates the capacity of water to react with acids or alkaline materials. $\mathrm{A} \mathrm{pH}$ higher than 8.5 generates sulphuric mineralization, imprinting a salty or bitter taste to the water, irritating the eyes and skin, while a pH lower than 6.5 affects the vitamin absorption in the body.

Dissolved oxygen is one of the most important parameters of opened water wells, offering data regarding the nutrients disponibility, the pollution level, the microorganism activities, and the stratification and photosynthesis of water [13]. The concentration of dissolved oxygen depends on the water temperature, air pressure and on the amount of oxidizable substances, microorganisms and hydro-geochemical processes [9,14]. A low amount of oxygen in water well decreases the freshness of water, inducing a vapid taste, reduces the auto purification capacity of water, favouring the persistence of pollution level and making it unsuitable for drinking $[5,15]$.

Total hardness is given by the concentrations of calcium and magnesium and it is a significant parameter in reducing the negative effects of toxic elements, increasing the boiling point of water and preventing the formation of foam as a result of the contact with soaps $[12,13]$. Consumption of hard water for a long period of time increases the incidence of anencephaly, cardiovascular disorders and cancer [1].

Total alkalinity represents the quality of all dissolved alkaline substances as carbonates $\left(\mathrm{CO}_{3}{ }^{2-}\right)$, bicarbonates $\left(\mathrm{HCO}_{3}{ }^{-}\right)$and hydroxides $\left(\mathrm{OH}^{-}\right)$, influencing the $\mathrm{pH}$ and neutralizing acids [2,12].

A source of chloride $\left(\mathrm{Cl}^{-}\right)$is represented by soluble chloride salts from minerals, which are essential in the activity of metabolism and other main physiological processes [1]. A high amount of chloride influences the content of chloride in groundwater and the amount of rain water and it is an indicator of contamination, causing negative effects (corrodation of pipeline systems, gives a salty taste to the water and causes diverse disorders: arterial hypertension, osteoporosis, asthma and kidney stones) [1,2].

Nitrate $\left(\mathrm{NO}_{3}{ }^{-}\right)$is related to precarious sanitation conditions, septic tanks situated nearby the water wells, sewage infiltration, fertilizers based on nitrogen $[1,16]$. Agricultural practices account for more than $50 \%$ of the total nitrogen spilled into water sources [13]. The antibacterial properties of nitrates play an important role in protecting the gastro-intestinal system against a variety of gastrointestinal pathogens, although a lifetime exposure at high concentrations could lead to health disease, such as diuresis and spleen haemorrhage [13]. 
A high amount of iron ( $\mathrm{Fe})$ in water is a result of geological debris, industrial and household wastes. In order to eliminate the iron from water, is achieved by filtration and drying [1]. High amount of iron has no negative effects on human health, but could generate a series of inconveniences, such as metallic taste and opalescent yellow colour $[1,17,18]$.

The aim of the study was to determine the physico-chemical parameters of water samples collected from water wells used as drinking water sources from the Remeți locality (situated in a protected area of Natura 2000). The determined parameters were selected considering their importance to the health of the consumers and also for the well functioning of the aquatic ecosystems nearby the Natura 2000 protected area along the Tisa River. Correlation among the indicators was established and the quality status was determined by applying the water quality index, calculated with the help of the results obtained for eleven physico-chemical parameters $(\mathrm{pH}$, electrical conductivity, ammonium, total hardness, turbidity, nitrite, nitrate, chloride, sulphate, iron and cooper) determined for the studied water samples.

\section{RESULTS AND DISCUSSIONS}

\section{Physico-chemical parameters}

The results of the analysed indicators (each value was the result of three measurements) present different dissimilarities with low variation coefficients for $\mathrm{pH}$, temperature, turbidity, electrical conductivity, ammonium and iron (Tables 1 and 2).

The measurements were repeteated three times, indicating repetability between the obtained results. Mean values are indicated in Table 1. The statistical analysis indicated normal distributions for the majoriy of the parameters, except for the depth and the water level, dissolved oxygen, carbonates and phospahtes, which indicated deviations from normality according to the standardized skewness and kurtosis from Table 2. The water level, depth, amount of $\mathrm{Cu}$, phosphate, nitrate, nitrite and dissolved oxygen indicated a high variability (65.7 - $105 \%$ ), showing the influence of external factors and contamination sources.

The water sample 10 has the highest depth, characterized by the highest dissolved oxygen content caused by the water temperature, air pressure and the content of oxidable substances and the activity of microorganisms. Samples 6, 7 and 8 have the lowest content of dissolve oxygen. Dissolved oxygen is important for the organisms, the high amount determined in sample $10(9.10 \mathrm{mg} / \mathrm{L})$ is due to the direct air diffusion or it was produced by autotroph organisms through photosynthesis [13]. Dissolved oxygen presents no direct danger for the human health, but could influence the chemical substances from water [13,19-22]. 
Table 1. Physico-chemical analysis of the studied groundwaters (samples 1-10)

\begin{tabular}{|c|c|c|c|c|c|c|c|c|c|c|}
\hline$\overbrace{\text { Parameter }}^{\text {Sample }}$ & 1 & 2 & 3 & 4 & 5 & 6 & 7 & 8 & 9 & 10 \\
\hline Depth, cm & 270 & 320 & 900 & 260 & 345 & 350 & 350 & 430 & 450 & 1180 \\
\hline Water level, cm & 220 & 230 & 800 & 220 & 275 & 280 & 280 & 360 & 310 & 590 \\
\hline Turbidity, NTU & 2.08 & 1.42 & 1.53 & 1.82 & 1.47 & 2.03 & 1.48 & 0.99 & 1.08 & 1.26 \\
\hline Temperature, ${ }^{\circ} \mathrm{C}$ & 16.9 & 19.3 & 16.6 & 19.9 & 19.7 & 18.1 & 18.4 & 16.4 & 16.0 & 15.5 \\
\hline \begin{tabular}{|l|} 
Electrical \\
conductivity, $\mu \mathrm{S} / \mathrm{cm}$
\end{tabular} & 654 & 558 & 616 & 572 & 525 & 463 & 639 & 786 & 543 & 590 \\
\hline $\mathrm{pH}$ & 7.31 & 7.12 & 7.71 & 7.38 & 7.14 & 7.53 & 7.39 & 7.51 & 7.68 & 7.97 \\
\hline Redox potential,mV & -22.5 & -11.6 & -45.6 & -21.2 & -12.9 & -35.2 & -26.9 & -34.3 & -43.9 & -60.4 \\
\hline Dissolved oxygen,mg/L & 3.58 & 3.38 & 5.56 & 4.45 & 4.73 & 2.79 & 2.44 & 2.27 & 3.66 & 9.10 \\
\hline Oxygen saturation, $\%$ & 38.9 & 37.2 & 62.3 & 43.8 & 52.5 & 30.1 & 25.8 & 23.8 & 40.1 & 92.8 \\
\hline Ammonium,mg/L & 1.66 & 1.92 & 2.38 & 2.38 & 1.09 & 1.49 & 1.16 & 1.41 & 2.22 & 1.93 \\
\hline Nitrate, $\mathrm{mg} / \mathrm{L}$ & 46.7 & 36.9 & 55.6 & 28.7 & 26.3 & 16.2 & 19.3 & 24.8 & 37.6 & 9.87 \\
\hline Nitrite, $\mathrm{mg} / \mathrm{L}$ & $\angle Q L^{*}$ & 0.001 & 0.002 & 0.003 & 0.002 & 0.001 & 0.001 & 0.003 & 0.004 & 0.002 \\
\hline Bicarbonate, mg/L & 122 & 183 & 232 & 207 & 159 & 195 & 170.8 & 305 & 183 & 195 \\
\hline Carbonate, mg/L & $<Q^{*}$ & $<Q L^{*}$ & $<Q L^{*}$ & $<Q L^{*}$ & $<Q^{*}$ & $<Q L^{*}$ & $<Q^{*}$ & $<Q^{*}$ & 58 & $<Q^{*}$ \\
\hline Sulphate, $\mathrm{mg} / \mathrm{L}$ & 0.39 & 0.65 & 0.84 & 0.93 & 0.55 & 0.57 & 0.63 & 0.63 & 0.88 & 0.65 \\
\hline Chloride, $\mathrm{mg} / \mathrm{L}$ & 26.0 & 19.0 & 16.0 & 11.0 & 18.0 & 12.0 & 21.0 & 13.0 & 14.0 & 15.8 \\
\hline Iron, mg/L & 0.024 & 0.025 & 0.018 & 0.023 & 0.024 & 0.024 & 0.024 & 0.028 & 0.027 & 0.024 \\
\hline Cooper, mg/L & $<Q^{*}$ & 0.01 & 0.02 & 0.01 & $<Q L^{*}$ & 0.02 & 0.01 & 0.02 & 0.01 & 0.02 \\
\hline Phosphate, mg/L & 0.15 & 0.07 & 0.16 & 0.11 & 0.06 & 0.09 & 0.12 & 0.17 & 0.38 & 0.78 \\
\hline Total hardness, ${ }^{\circ} \mathrm{G}$ & 7.2 & 8.5 & 15.5 & 7.9 & 9.1 & 9.5 & 9.3 & 11.5 & 12.4 & 19.3 \\
\hline
\end{tabular}

In all the studied samples, turbidity is lower than the guideline value (5 NTU). The highest value was obtained in sample 8, due to the household wastes and leakage of chemical substances used in agricultural and beekeeping practices [1]. The turbidity increases during rainfall especially in the case of low depth groundwater [23].

The $\mathrm{pH}$ varies between 7.12 and 7.97 and it is related to the predominant soil type or to the accumulation of organic materials, while the degradation of the organic substances is caused by the release of carbon dioxide and by the reaction with the water producing carbonic acid [13].

The low values of electrical conductivity (sample 6) are due to the low content of inorganic substances dissolved in ionized form and due to the dilution effect of groundwater from water wells during precipitation [13, 24]. High electrical conductivity is caused by the presence of high amount of dissolved inorganic substances [12, 25].

The presence of ammonium in water is a result of incomplete degradation of organic substances based on nitrogen and of the water-soil interaction. The obtained results are three to four times higher than the 
parametric value $(0.5 \mathrm{mg} / \mathrm{L})$ established by the Council Directive 98/83/EC. Nitrate is very mobile in soil and in groundwaters, because it is not adsorbed by the soil or by the geological material, precipitating only in dry conditions as mineral [25]. The amount of nitrate in the environment comes from a variery of sources, including agricultural activities (use of organic and chemical fertilizers based on nitrogen) and household activities (septical tanks and sewage system) [13]. The consumption of water rich in nitrates could induce methemoglobinemia or the blue baby syndrome in infants [25].

Phosphate ranges between $0.06-0.78 \mathrm{mg} / \mathrm{L}$, having an average of $0.209 \mathrm{mg} / \mathrm{L}$. Sources of phosphate are represented by the interactions of water with rocks and soil, the use of phosphorus fertilizers and detergents (phosphates are added as softeners). Sample 10 is characterized by the highest phosphate amount $(0.40 \mathrm{mg} / \mathrm{L})$. It was demonstrated that long-term over-application of manure and chemical fertilizer determine the orthophosphate movement into the groundwater system and consequently contaminates the groundwater resources [26]. Low amount of phosphate is observed in samples $2,4,5,6$ and 7 , while samples 1,3 and 8 are characterized by a medium amount, possibly due to the leakage of inorganic fertilizers [13]. Rich water in phosphate influences the development of algae, changing and altering the taste and colour of water [13].

The total hardness is influenced by the soil composition and by the presence of undissolved calcium and magnesium [1]. Water samples 1, 2, 6 and 8 have low values for the total hardness, which is corrosive and could dissolve heavy metals [1]. The consumption of water with high amounts of calcium and magnesium (sample 9) could cause deposition of salts (kidney, bones and gallbladder). Likewise, it is characterized by an unpleasant taste, causing indigestion and deposition of calcium oxalate crystals on the urinary tract $[1,13,17]$.

The content of chloride varies between $11.0-26.0 \mathrm{mg} / \mathrm{L}$. Sources of chloride are disinfectants used in water purification, manure and chemical fertilizers used in agriculture, also irrigation, excessive use of groundwater, infiltration of wastewaters, leakage from waste deposits, the interaction of water with the geological layers, degradation of rocks, minerals and soils [6, $13,19,20,24,27]$. High amount of chloride increases the electrical conductivity and implicitly the capacity of water corrosion [12]. Chloride reacts with the metallic ions from the pipeline system forming soluble salts which increases the amounts of metals in the drinking water [18, 24]. Water rich in chloride induces laxative effects [12].

Carbonate varies between 0.01 and $58.0 \mathrm{mg} / \mathrm{L}$. The presence of carbonates in groundwater used as drinking water sources (water well) is due to the interaction of water with degraded granites and gnais or due to the dissolution of carbonate and carbonic acid silicate minerals [27-29]. 
Sulphate ranges between 0.39 and $0.88 \mathrm{mg} / \mathrm{L}$ and it appears naturally in groundwater by sulphide dissolution (pyrites) [13]. The low amount of sulphate is given by the geological profile, the low amount of sulphurous minerals, the interaction of rain water with soil, nitrates reduction, organic matter, household waste and untreated industrial waste [13, 27, 28]. The presence of sulphate in groundwater is due to the dissolution of sulphate rocks, oxidation of sulphurous minerals or decomposition of animal and vegetal substances which contain sulphur [14].

The variation of $\mathrm{pH}$, alkalinity, dissolved oxygen, organic matter, microorganisms and temperature disturbes the solid-liquid equilibrium between the corrosion scale and water phase; this way iron is released into the drinking water [21, 22]. The hydrolysis of Fe(II) in the presence of dissolved oxygen generates $\mathrm{Fe}(\mathrm{OH})_{3}$, causing water slurry [13]. The determined concentrations of iron in the studied samples are low $(0.02-0.03 \mathrm{mg} / \mathrm{L})$, having different sources: the chemical decomposition of ferruginous deposits, rocks, minerals and the dissolution of iron minerals [29].

Table 2. Summary statistics of physico-chemical characteristics of the analysed groundwaters

\begin{tabular}{|c|c|c|c|c|c|c|c|}
\hline $\begin{array}{c}\text { Statistical } \\
\text { indicator }\end{array}$ & Average & $\begin{array}{l}\text { Standard } \\
\text { deviation }\end{array}$ & Min & $\operatorname{Max}$ & $\begin{array}{c}\text { Coeff. } \\
\text { variation } \\
\%\end{array}$ & $\begin{array}{c}\text { Guideline } \\
\text { value* }^{*}\end{array}$ & $\begin{array}{c}\text { Parametric } \\
\text { value }^{\star *}\end{array}$ \\
\hline Depth, cm & 485 & 305 & 260 & 1180 & 62.9 & - & - \\
\hline Water level, $\mathrm{cm}$ & 356 & 190 & 220 & 800 & 53.3 & - & - \\
\hline Turbidity, NTU & 1.52 & 0.37 & 0.99 & 2.08 & 24.3 & 5.0 & 5.0 \\
\hline Temperature,${ }^{\circ} \mathrm{C}$ & 17.7 & 1.61 & 15.5 & 19.9 & 9.10 & 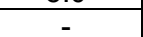 & - \\
\hline $\begin{array}{l}\text { Electrical conductivity, } \\
\mu \mathrm{S} / \mathrm{cm}\end{array}$ & 595 & 87.7 & 463 & 786 & 14.7 & 2500 & 2500 \\
\hline $\mathrm{pH}$ & 7.47 & 0.26 & 7.12 & 7.97 & 3.53 & $6.5-8.5$ & 9.5 \\
\hline Redox potential, mV & -31.4 & 15.49 & -60.4 & -11.6 & -49.2 & - & - \\
\hline Dissolved oxygen, $\mathrm{mg} / \mathrm{L}$ & 4.20 & 2.01 & 2.27 & 9.10 & 47.9 & - & - \\
\hline Oxygen saturation, \% & 44.7 & 20.6 & 23.8 & 92.8 & 45.9 & - & - \\
\hline Ammonium, $\mathrm{mg} / \mathrm{L}$ & 1.76 & 0.48 & 1.09 & 2.38 & 27.0 & 35 & 0.5 \\
\hline Nitrate, $\mathrm{mg} / \mathrm{L}$ & 30.2 & 14.1 & 9.87 & 55.6 & 46.7 & 50 & 50 \\
\hline Nitrite, $\mathrm{mg} / \mathrm{L}$ & 0.002 & 0.001 & $<Q^{* * *}$ & 0.004 & 63.0 & 3.0 & 0.5 \\
\hline Bicarbonate, $\mathrm{mg} / \mathrm{L}$ & 195 & 48.4 & 122 & 305 & 24.8 & - & - \\
\hline Carbonate, $\mathrm{mg} / \mathrm{L}$ & 5.80 & 18.3 & $<Q L$ & 58.0 & 316 & - & - \\
\hline Sulphate, $\mathrm{mg} / \mathrm{L}$ & 0.67 & 0.17 & 0.39 & 0.93 & 24.7 & 250 & 250 \\
\hline Chloride, $\mathrm{mg} / \mathrm{L}$ & 16.6 & 4.57 & 11.0 & 26.0 & 27.6 & - & 250 \\
\hline Iron, mg/L & 0.02 & 0.003 & 0.02 & 0.03 & 11.0 & - & 0.2 \\
\hline Cooper, mg/L & 0.01 & 0.01 & $<Q L^{* * *}$ & 0.02 & 65.7 & 2.0 & 2.0 \\
\hline Phosphate, mg/L & 0.21 & 0.22 & 0.06 & 0.78 & 105 & - & - \\
\hline Total hardness, ${ }^{\circ} \mathrm{G}$ & 11.0 & 3.81 & 7.2 & 19.3 & 34.5 & - & 5.0 \\
\hline \multicolumn{8}{|c|}{$\begin{array}{l}{ }^{*} \text { guideline value according to the WHO Guidelines for drinking-water quality [30] } \\
{ }^{* *} \text { parametric value, according to the Council Directive 98/83/EC on the quality of water } \\
\text { intended for human consumption [31] } \\
{ }^{* * *} \text { quantification limit of the method }\end{array}$} \\
\hline
\end{tabular}


THOMAS DIPPONG, CRISTINA MIHALI, OANA MARE ROSCA, MONICA MARIAN, ...

\section{Cluster analysis}

Cluster analysis is a useful tool in the analysis of hydrochemical data $[17,32,33]$. According to the physico-chemical characteristics, the level and depth of the groundwater collected from water wells were classified in two homogenous clusters: $\mathrm{C} 1$ and $\mathrm{C} 2$. Figure 1 indicates the dendrogram of the analysed samples. $\mathrm{C} 1$ comprises six samples with low and medium level and depth and also with medium values of the total hardness and $\mathrm{HCO}_{3}{ }^{-}$, while C2 contains the samples characterized by higher values of total hardness, $\mathrm{PO}_{4}{ }^{3}$ and lower dephts. The groundwater samples grouped in $\mathrm{C} 1$ are located in the western part of the locality except for sample 3 , while cluster C2 comprises mainly the groundwater samples located in the eastern part of Remeți locality (close to Tisa River).

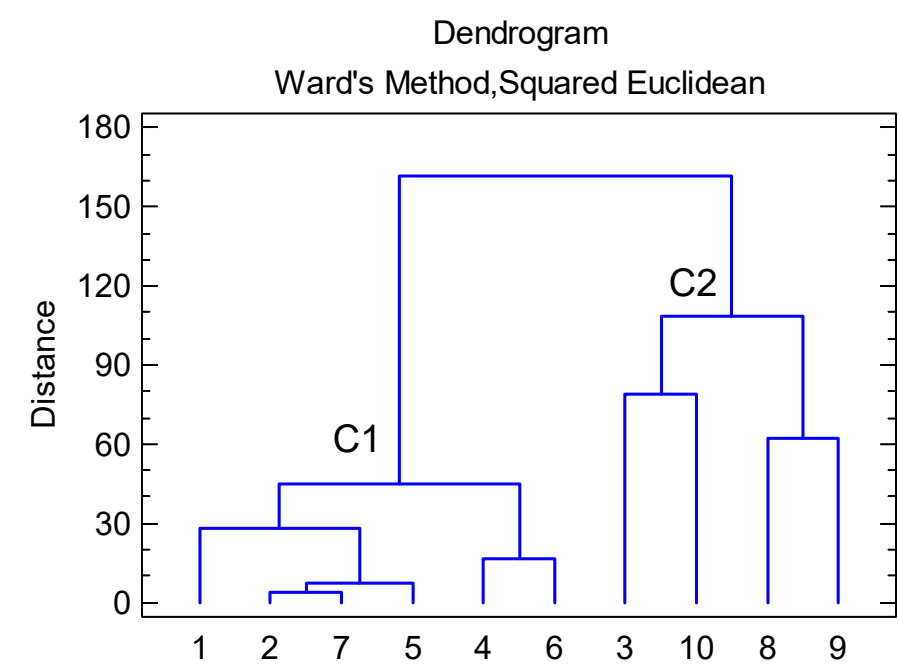

Figure 1. Cluster analysis of groundwater samples based on the physico-chemical characteristics

\section{The Water Quality Index (WQI)}

The WQI was calculated for eleven physico-chemical parameters $(n=11)$. The values calculated for the weightage factor corresponding for each indicator are $w_{i \mathrm{pH}}=0.11 ; w_{i \mathrm{EC}}=0.0004 ; w_{i \mathrm{NH} 4, \mathrm{NO} 2}=2.0 ; w_{i}$ total hardness, $\mathrm{NO}$,

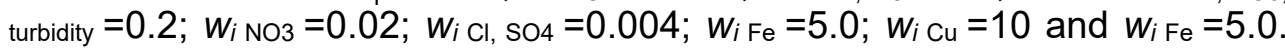
According to the WQI results, the studied groundwater samples are characterized with good and excellent quality. Samples characterized by good quality vary between 57.1 and 65.1 , while samples characterized by excellent quality range between 27.7 and 49.8 (Figure 2). 


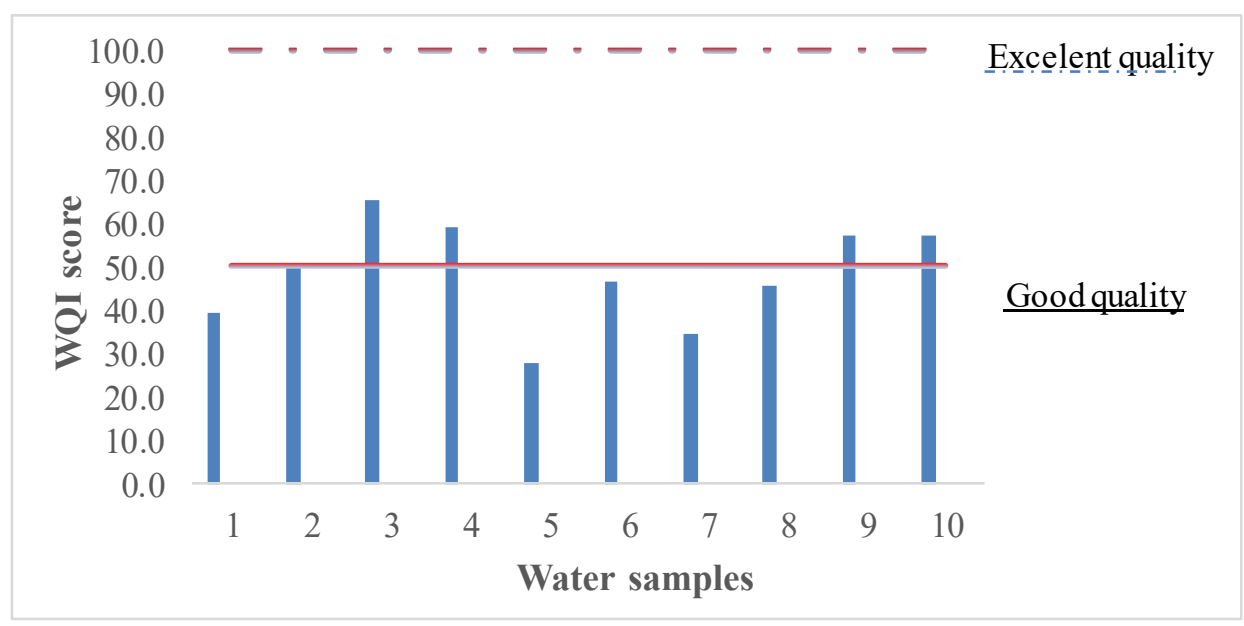

Figure 2. The water quality classification according to the WQI scores

The highest score was obtained for sample 3 , followed by samples $4>10>9>2>6>8>1>7>5$. The highest score obtained for sample 3 is correlated with the high amount of nitrate $(55.6 \mathrm{mg} / \mathrm{L})$ and ammonium $(2.38 \mathrm{mg} / \mathrm{L})$; the concentrations exceed the parametric values established by the Council Directive 98/83/EC (50 mg/L NO${ }_{3}{ }^{-}$and $0.5 \mathrm{mg} / \mathrm{L} \mathrm{NH}_{4}{ }^{+}$). The WQI scores for samples 4,9 and 10 are correlated with the high amounts of nitrate, ammonium and values of the total hardness.

Other studies conducted in Romania indicate good to excellent quality as well, with values ranging from 24.1 to 89.8 in the southeastern part of the country (Dobrogea). Excellent, good, poor and very poor quality were determined in the northwestern part of the country (Maramures County) with values ranging from 5.7 to 97.2 . The poor quality was due to the high concentrations of nitrates, nitrites and iron [17, 34]. In the central-eastern part of the country, groundwater used as drinking water sources collected from water wells was characterized by excellent and good, poor quality. The WQI scores ranged between 2.4 and 75.0 [35]. At international level, groundwater is characterized by different quality categories, such as poor, good and excellent in Burdur, Turkey (WQI ranging between 17.4-111) [36]. Unsuitable water for drinking, very poor, poor and good quality of waters were determined in Delhi, India (WQI: 50-300) and in Guanzhong Basin, China (WQI: 21.1-967) [37-38]. 
THOMAS DIPPONG, CRISTINA MIHALI, OANA MARE ROSCA, MONICA MARIAN, ...

\section{CONCLUSION}

Temperature, dissolved oxygen, oxygen saturation, $\mathrm{pH}$, and phosphate levels all increase with depth, while nitrate levels fall. All water samples have low turbidity with normal total hardness levels (except for sample 9, which has a relatively high total hardness). The chloride, sulphate, iron, and cooper contents and the electrical conductivity values are below the guideline and parametric values.

Cluster analysis indicated two groups of similarity. The first cluster contains the groundwater samples situated in the eastern part of the locality, characterized by low depth. The second cluster consists of the samples localized in the western part of the locality, characterized by high depths and high values of the total hardness (due to the rock weathering processes).

The data regarding the water composition are useful for a more efficient water management. The rise in nutrient levels (ammonium, nitrate and phosphate) could be limited by applying a rational use of chemical fertilizers and by improving the protection areas.

According to the WQI, the studied samples are characterized as waters with generally excellent and good quality. The good quality is correlated with the high amount of nitrate and ammonium.

The novelty of this paper consists in the presentation of groundwater characteristics in relation to the anthropogenic pressure on the water wells situated nearby the Tisa River protected area. A sustainable economic development needs systematic and careful observation of the anthropogenic actions' effects on the environment, especially in protected areas, as a support for rational natural resources management.

\section{EXPERIMENTAL SECTION}

\section{Sampling location}

Remeți locality is situated in the alluvial plain of Tisa River, a part of this area being protected at national and international level (part of Natura 2000 Tisa Superioara site), as it contains habitats with a significant biodiversity of important fauna and flora. Studying the groundwater quality from this area could protect the health of the inhabitants using it for drinking purposes and the possible anthropogenic pressures on the ecosystems from the site could be minimized or even stopped.

The groundwater samples were collected from Remeți, a village located in the Tisa meadow near the border with Ukraine, presented in Figure 3. Data regarding the depth of the water wells was obtained by measuring the water 
well on the levels, while the level of water was determined with the help of a tape meter tool, by measuring the distance from the bottom to the surface of the water.

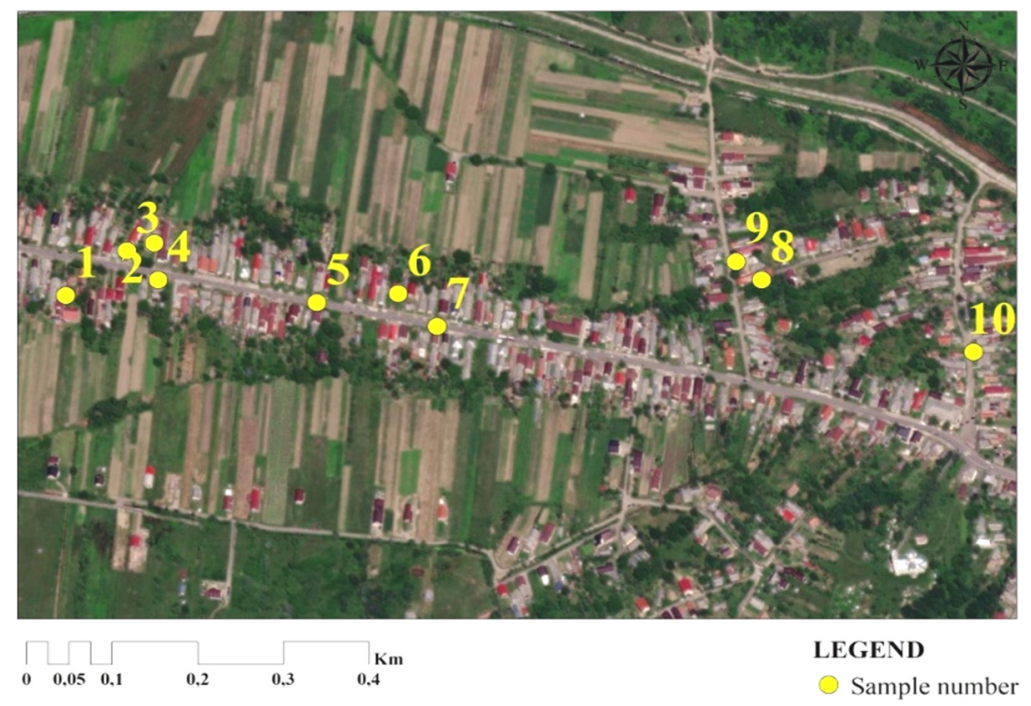

Figure 3. Localization of groundwater samples collected from water wells from Remeți locality

Groundwater bodies in the village of Remeți, which is located in the floodplain of the Tisa river and along its tributary, Remeți, have developed into permeable alluvial deposits of recent age (Quaternary) [23].

\section{Water sample collection and analysis}

A number of 10 groundwater samples were collected in September of 2020 from open private water wells.

The sampling was performed in clean polypropylene bottles $(500$ $\mathrm{mL})$. Part of the physico-chemical analyses were performed on the field $(\mathrm{pH}$, electrical conductivity, redox potential) and part in the laboratory. The determination of $\mathrm{pH}$ was performed according to SR ISO 10523/2012, the redox potential according to SR ISO 10523/2012, the dissolved oxygen and oxygen saturation according to SR EN ISO 5814:2013, the ammonium concentration according to SR ISO 7150-1/2001, the nitrate concentration according to SR ISO 7890-3/2000 employing Hach Lange HQ40d portable 
equipment. The nitrite concentrations were determined in accordance with SR ISO 6777/2002, the phosphates following STAS 3265-86, the iron following SR ISO 6332:1996, the copper following SR ISO 8288/2001, the total alkalinity with SE EN ISO 9963-1/1996, employing a Hach Lange SL1000 portable equipment [3]. Total hardness of water consists in the joint determination of $\mathrm{Ca}$ and $\mathrm{Mg}$ cations by their complexometric titration with the sodium salt of ethylenediamine tetraacetic acid ( $\left.\mathrm{Na}_{2} \mathrm{EDTA}\right)$ in the presence of the metallochrome indicator Eriochrome Black $\mathrm{T}$ and of a pH buffer (to 10.1 ) according to a standardized method (STAS $7313-82$ ). Sulphates are analysed by a turbidimetric method based on the precipitation of sulfate anions (barium sulphates) by adding barium chloride reagent, according to the EPA method [39]. The absorbances of the resulted suspensions are measured at $420 \mathrm{~nm}$ with a Perkin Elmer Lambda 25 spectrophotometer. The equipment was calibrated with standard sulphate solutions. Chlorides were determined by precipitation titration against $\mathrm{AgNO}_{3}$, according to the ISO 9297-2001 standard.

\section{Cluster analysis}

The data regarding the physico-chemical parameters of groundwater samples are subjected to cluster analysis in order to classify the groundwater samples using the Ward's grouping method and squared Euclidean distance between the observations (the analysed groundwater collected from water wells) considering the depth and level of the water wells as variable. Likewise, the analysed physico-chemical parameters (except the degree of oxygen saturation and the redox potential) were correlated to the dissolved oxygen and $\mathrm{pH}$. Cluster analysis is applyied by using Statgraphic software, used also for the statistical determinations (standardized skewness and kurtosis).

\section{The Water Quality Index (WQI)}

The WQI represents a rating, indicating the composition influence of a series of physico-chemical indicators [40]. The calculation of the WQI involves three steps: 1 . the calculation of the weightage factor $\left(w_{i}\right)$ for each physico-chemical parameter, 2. the determination of the quality rating scale $\left(Q_{i}\right)$ and 3. the calculation of the WQI [41]. The following equations [eq 1-3] are used in order to determine the WQI, based on the studies of Das Kangabam et al., Babu et al., Srinivas et al. and Goher et al. [41-44]: 


$$
w_{i}=\frac{1}{p_{v}}
$$

where $w_{i}$ and $p_{v}$ are the weightage factor of each physico-chemical parameter, 1.0 is a proportionality constant, according to Babu et al. (2006), Srinivas et al (2011) and Goher et al. (2014), while $p_{v}$ is the parametric value established by the Council Directive for the drinking water, indicated in Table 3 [42-44].

$$
\begin{gathered}
Q_{i}=\left[\frac{C_{i}-V_{i}}{p_{v}-V_{i}}\right] \times 100 \\
W Q I=\frac{\sum_{i=1}^{n}\left(Q_{i} \times w_{i}\right)}{\sum_{i=1}^{n} w_{i}}
\end{gathered}
$$

where $Q_{i}$ is the quality rating scale, $C_{i}$ is the measured values of each physico-chemical parameters, $V_{i}$ is the ideal value of the chemical indicator $\left(V_{i}=0\right.$ for all applied indicators except for $\left.\mathrm{pH}, V_{i p H}=7\right)$ and $n(n=11$ in the current study) is the total number of the used indicators [41].

Results are expressed in numerical scores (0-100) indicating the quality status of the studied water. There are five quality classes, namely unsuitable for drinking (WQI>300), water with very poor quality (WQI: 200300), poor quality (WQI: 100-200), good quality (WQI: 50-100) and excellent quality $(\mathrm{WQ}<<50)[40]$.

\begin{tabular}{|c|c|c|c|c|}
\hline $\begin{array}{l}\text { Physico-chemical } \\
\text { indicator }\end{array}$ & Unit & $\begin{array}{c}\text { Parametric } \\
\text { value }\left(p_{v}\right)^{*}\end{array}$ & Weight $\left(w_{i}\right)^{\star *}$ & Variation of $Q^{\star * *}$ \\
\hline $\mathrm{pH}$ & - & 9.5 & 0.11 & $4.80-38.8$ \\
\hline Electrical conductivity & $\mu S / c m$ & 2500 & $4 * 10^{-4}$ & $18.5-31.4$ \\
\hline Ammonium & $\mathrm{mg} / \mathrm{L}$ & 0.5 & 2.00 & $218-476$ \\
\hline Total hardness & ${ }^{\circ} \mathrm{G}$ & 5.0 & 0.20 & $144-386$ \\
\hline Turbidity & NTU & 5.0 & 0.20 & $19.8-41.6$ \\
\hline Nitrite & $\mathrm{mg} / \mathrm{L}$ & 0.5 & 2.00 & $0.00-0.80$ \\
\hline Nitrate & $\mathrm{mg} / \mathrm{L}$ & 50 & 0.02 & $32.4-111$ \\
\hline Chloride & $\mathrm{mg} / \mathrm{L}$ & 250 & $4^{*} 10^{-3}$ & $4.40-10.4$ \\
\hline Sulphate & $\mathrm{mg} / \mathrm{L}$ & 250 & $4^{*} 10^{-3}$ & $0.16-0.35$ \\
\hline Iron & $\mathrm{mg} / \mathrm{L}$ & 0.2 & 5.00 & $9.00-13.5$ \\
\hline Cooper & $\mathrm{mg} / \mathrm{L}$ & 2.0 & 10.0 & $0.00-20.0$ \\
\hline \multicolumn{5}{|c|}{$\begin{array}{l}\text { *according to the Council Directive } 98 / 83 / E C \text { [31] } \\
\text { **according to Das Kangabam et. al [41] } \\
\text { ***the rating scale for each physico-chemical indic }\end{array}$} \\
\hline
\end{tabular}

Table 3. The physico-chemical indicators used in the calculation of WQI, the used parametric values, the weight and the variation of the rating scale 
For the calculation of the WQI in the present study, eleven physicochemical indicators are considered: $\mathrm{pH}$, electrical conductivity, total hardness, turbidity, ammonium, nitrite, nitrate, chloride, sulphate, iron and cooper and the parametric values proposed by the Council Directive 98/83/EC regarding the quality of water intended for human consumption (Table 3 ).

\section{REFERENCES}

1. A.H. Jagaba; N.M.Y. Almahbashi; Ain Shams Eng J, 2020, 11, 983-999.

2. O.N. Sila; Scientific African, 2019, 2, e00018.

3. T. Dippong; C. Mihali; E. Cical; Metode de determinare a proprietăților fizicochimice ale alimentelor, Risoprint Cluj-Napoca, Romania, 2016.

4. R. Mihaiescu, Monitoringul integrat al mediului, Cluj-Napoca, Romania, 2014.

5. J. Gentry-Shields; J. Bartram; Sci Total Environ, 2014, 468-469, 306-314.

6. G. Hanrahan; Surface and Groundwater monitoring. In Key concepts in Environmental Chemistry, Academic Press, Elservier, Amsterdam, 2012, pp. 109-152.

7. N. Adimalla; H. Qian; M.J. Nandan; Ecotoxicol Environ Saf, 2020, 206, 111217.

8. O. lacob; A. Tudor; A. Neamţu; A. Cristea; Apa de fântână: contaminarea cu nitraţi şi methemoglobinemia Ghid pentru medici de familie, medici igienişti DSP şi populaţie. Universitara Press, Bucureşti, Romania, 2012.

9. A. Racariu; A. Urzica; C. Stoleriu; East Europ J Geograph Info Systems Remote Sensing, 2018, 2.

10. K.P Singh; S. Gupta; D. Mohan; J Hydrol, 2014, 511, 254-266.

11. V.A. Nemtinov; Y.V. Nemtinov; A.B. Borisenko; K.V. Nemtinov; J Geochem Explor, 2014, 147, 46-51.

12. I.N. Karthika; K. Thara; M.S. Dheenadayalan; Mater Today: Proceedings, 2018, $5,422-428$.

13. T.A. Adesakin; A.T. Oyewale; U. Bayero; A.N. Mohammed; I.A. Aduwo; P.Z. Ahmed; N.D. Abubakar; I.B. Barje; Heliyon, 2020, 6, e04779.

14. H. Çadraku; F. Gashi; A. Shala; O. Fetoshi; IFAC-PapersOnLine, 2016, 49-29, 200-205.

15. M. Surpateanu; Elemente de chimia mediului, MatrixRom, Bucuresti, Romania, 2004.

16. J. Liu; Y. Peng; C. Li; Z. Gao; S. Chen; J Clean Prod, 2021, 282,125416.

17. T. Dippong; C. Mihali; M.A. Hoaghia; E. Cical; A. Cosma; Ecotox Environ Saf, 2019, 168, 88-101.

18. O. Cadar; M. Miclean; S. Cadar; C. Tanaselia; L. Senila; M. Senila; Environ Eng Manag J, 2015, 14, 2523-2528.

19. M.K. Samantara; R.K. Padhi; M. Sowmya; P. Kumaran; K.K. Satpathy; Groundw Sustain Dev, 2017, 5, 49-58. 
20. M. Kumar; A. Puri; J Occup Environ Med, 2012, 16, 40.

21. F. Yang; B. Shi; J. Gu; D. Wang; M. Yang; Water Resear, 2012, 46, 5423-5433.

22. C-Y. Peng; G. V. Korshin; L. Richard; R. L Valentine; A. S. Hill; M. J. Friedman; H. Steve; S. H. Reiber; Water Resear, 2010, 44, 4570-4580.

23. G. Şerban; D. Sabău; R. Bătinaș; P. Brețcan; E. Ignat;S. Nacu; Water resources from Romanian Upper Tisa Basin. In Water Resour Manag Romania, 2020, 393-436.

24. S. Sargazi; M. Mokhtari; M.H. Ehrampoush; S.A. Almodaresi; H. Sargazi; M. Sarhadi; Groundw Sustain Dev, 2021, 12, 100509.

25. R. Arulnangai; M.M. Sihabudeen; P.A. Vivekanand; P. Kamaraj; Mater Today: Proceedings, 2021, 36, 923-928.

26. J.L. Domagalski; H. Johnson; Studies by the U.S. Geological Survey on sources, transport, and fate of agricultural chemicals, U. S. Geological Survey Fact Sheet 2012.

27. N. Zakaria; G. Anornu; D. Adomako; F. Owusu-Nimo; A. Gibrilla; Groundw Sustain Dev, 2021, 12, 100489.

28. A. Ramachandran; K. Sivakumar; A. Shanmugasundharam; U. Sangunathan; R.R. Krishnamurthy; Acta Ecologica Sinica, 2020.

29. A.M. Masoud; M.H. Ali; J African Earth Sci, 2020, 172, 103982.

30. WHO, 2017, Guidelines for drinking-water quality, 4th ed. Incorporating first addendum. World Health Organization, Geneva, Switzerland.

https://www.who.int/publications//item/9789241549950 (accessed on 14 January 2021).

31. Council Directive 98/83/EC of 3 November 1998 on the quality of water intended for human consumption.

https://eur-lex.europa.eu/legal-

content/EN/TXT/PDF/?uri=CELEX:31998L0083\&from=EN (accessed on 03 December 2020).

32. J. Wu; P. Li; H. Qian; Environ Earth Sci, 2015, 73, 8575-8588.

33. A. Nagaraju; A. Thejaswi; Y. Sreedhar; Earth Sci Resear J, 2016, 20, E1-E7.

34. A. Moldovan; M.-A. Hoaghia; E. Kovacs; I.C. Mirea; M. Kenesz; R.A. Arghir; A. Petculescu; E.A. Levei; O.T. Moldovan; Water, 2020, 12, 3510.

35. C.A. Roba; I.C. Pistea; E. Neagoe; A.O. Matei; C. Rosu; Sci Paper Series Manag, Econ Eng Agriculure Rural Dev, 2019, 19, 491-496.

36. S. Varol; A. Davraz; Environ Earth Sci, 2014, 73, 1725-1744.

37. S. Acharya; S.K. Sharma; V. Khandegar; Data in Brief, 2018, 18, 2019-2028.

38. Q. Zhang; P. Xu; H. Qian; Expos Health, 2020, 12, 487-500.

39. US EPA, 1979 Sulfate (turbidimetric). Method 375.4, Methods for the Chemical Analysis of Water and Wastes, EPA/600/4-79/020. US Environmental Protection Agency, Washington DC, USA

40. S. Singh; A. Hussian; Cogent Eng, 2016, 3.

41. R. Das Kangabam; S.D. Bhoominathan; S. Kanagaraj; M. Govindaraju; Appl Water Sci, 2017, 7, 2907-2918.

42. R.C. Babu; R. Chandana; O.S.S. Sudarsana, T. Rao; J. Suresh Kumar; Nat Environ Pollut Technol, 2006, 5, 203-207. 
THOMAS DIPPONG, CRISTINA MIHALI, OANA MARE ROSCA, MONICA MARIAN, ..

43. P. Srinivas; G.N. Pradeep Kumar; A. Srinivasa Prasad; T. Hemalatha; Civil Environ Res, 2011, 1, 9-20.

44. M.E. Goher; A.M. Hassan; I.A. Abdel-Moniem; A.H. Fahmy; S.M. El-sayed; Egypt J Aquat Res, 2014, 40, 225-233. 